\title{
Influence of Investment Decisions, Corporate Social Responsibility and Company Growth in Companies Manufacturing of the Sub-Sector of Consumption Goods Registered in Indonesia Stock Exchange Year 2017-2019
}

\author{
Anggiat Sinurat ${ }^{1}$, Elfina Okto Posmaida Damanik ${ }^{2}$, Risma Munthe ${ }^{3}$, Eva Sriwiyanti ${ }^{4}$, \\ Sri Martina ${ }^{5}$ \\ 1,2,3,4,5 Faculty of Economics, Universitas Simalungun, Indonesia \\ angginoer@gmail.com,elfinaopdse83@gmail.com,rismamunthe66@gmail.com, \\ evasriwiyanti.s@gmail.com,srimartina999@gmail.com
}

\begin{abstract}
This study aims to determine the effect of investment decisions, corporate social responsibility and company growth in consumer goods manufacturing companies listed on the Indonesia Stock Exchange in 2017-2019. Several previous studies on different firm values. Therefore, other research needs to be done to retest the theory of value. The research data is obtained from sample companies which can be downloaded from the Indonesia Stock Exchange website. The data analysis technique used is multiple regression analysis. The data analysis process that is done first is the classical assumption test, multiple regression analysis and then testing the hypothesis. The results of the study partially show that only investment decisions have a positive and significant effect on firm value. Meanwhile, the growth of companies and corporate social responsibility has no effect on firm value. The results of the research simultaneously show that corporate social responsibility and company growth have a significant effect on firm value.
\end{abstract}

Keywords

investment decisions, corporate social responsibility, company growth and company value

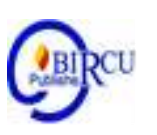

\section{Introduction}

The development of the business world is getting tighter and the economic situation is unstable at this time, making companies must have the ability to survive. Efforts that can be made by the establishment of a company are to implement various strategic policies that result in efficiency and effectiveness for the company. One of the things that is important in company value (Tarigan, 2019). Firm value is one of the attractions for investors of a company which is related to the stock price. A company is said to have a good value if the company's performance is also good. The higher the stock price, the higher the company's value. Firm value is a certain condition that has been achieved by a company as a reflection of the firm's value belief can describe the condition of the company. With low or poor company value, potential investors will view the company as not suitable as their investment alternative. Likewise on the contrary, high firm value indicates good company performance. One of them is the view of the value of the company for the creditor. Investors' perceptions of the company's success rate are reflected in the company's value. The increase in company value due to the high stock price will make the market believe in the company's performance and its prospects in the future. Increasing company profits and maximizing company value are interrelated company goals to improve the welfare of 
shareholders, so that these goals will become important criteria for maintaining the survival of the company (Tarigan, 2019).

Firm value is one of the attractions for investors of a company which is related to the stock price. A company is said to have a good value if the company's performance is also good. The higher the stock price, the higher the company's value. Firm value is a certain condition that has been achieved by a company as a reflection of the firm's value belief can describe the condition of the company. With low or poor company value, potential investors will view the company as not suitable as their investment alternative. Likewise on the contrary, high firm value indicates good company performance. One of them is the view of the value of the company for the creditor. Investors' perceptions of the company's success rate are reflected in the company's value. The increase in company value due to the high stock price will make the market believe in the company's performance and its prospects in the future. Increasing company profits and maximizing company value are interrelated company goals to improve the welfare of shareholders, so that these goals will become important criteria for maintaining the survival of the company (Tarigan, 2019).

Every company certainly wants their company value to always increase, as well as investors. Because, with increasing score company will maketheir welfare increase as well. However, in reality the value of the company always changes and does not always increase so that the desired welfare will be difficult to achieve.

The first factor that is thought to affect firm value is investment decisions. Investment decisions are very important because they will affect the successful achievement of company goals. The value of the company, which is formed through stock market value, is strongly influencedby investment opportunities. Based on signaling theory, spending investment shows a positive signal about the growth of the company's assets in the future, thus increasing the stock price as an indicator of the company's value.

In investment decisions, companies are faced with decisions about how much funds should be invested in current assets and fixed assets as well as items related to other assets of the company.

The next factor that is thought to influence firm value is Corporate Social Responsibility (CSR). In addition to providing benefits to stakeholders, CSR activities are also expected to be able to provide distinct benefits to the company, namely by maintaining and enhancing the company's reputation and brand image which creates a positive corporate image. The increase in company value is a long-term goal that should be achieved by a company which will be reflected in its share price because investors' assessment of a company can be observed through stock price movements transacted on the stock exchange for companies that have gone public. The higher the stock price, the higher the value of the company which shows the prospects for the company in the future. Increasing Corporate Social Responsibility to society will create a good image towards the company, investors are more interested in companies that have dim a good image in society because the better the company image, the better consumption loyalty.

The last factor that is thought to affect firm value is the growth of the company. Good company growth is expected to generate a higher rate of return on the investment made. Investors who obtain information about the growth of the company as indicated by the increase in the total assets of a company will get a good response from the market, so that it can increase the stock price or reflect the increased company value. Pramusinto and Daerobi (2020) stated that the development of the manufacturing industry in the digital era will increase productivity and industrial competitiveness.

The object of research was carried out at manufacturing companies in the consumer goods industry sector which were listed on the Indonesia Stock Exchange (BEI) in 2017- 
2019. The reason for choosing companies engaged in manufacturing companies in the consumer goods industry sector is because companies engaged in this sector are quite attractive to investors because it has been proven through the resilience of the manufacturing sector, especially supported by the consumer sector. Based on the background of the problem above, the formulation of the problem is as follows: Do investment decisions, corporate social responsibility (CSR) and company growth have a significant effect on the value of the company in the consumer goods sub-sector manufacturing company listed on the Indonesia Stock Exchange 2017 - 2019?.

The purpose of this study is to determine and analyze the effect of investment decisions, corporate social responsibility (CSR), company growth on firm value in consumer goods sub-sector manufacturing companies listed on the Indonesia Stock Exchange 2017 2019.

\section{Review of Literature}

\subsection{Company Value (Y)}

According to Harmono(2011) score company is a performance company which is reflected by the stock price which is formed by the supply and demand in the capital market which reflects the community's assessment of the company's performance.

The value of a company can be reflected in its share price. High share price makes the company value also high. A company is said to have a good value if the company's performance is also good. If the stock value is high, it can be said that the company value is also good. Because the main objective of the company is to increase the value of the company through increasing the prosperity of the owner or shareholders.

Firm value can be measured by price to book value (PBV), which is the ratio between stock price and book value per share (Brigham and Gapenski in Fau, 2015). A high PBV will make investors confident about the company's prospects in the future.

Therefore, the existence of the PBV ratio is very important for investors and potential investors to make investment decisions. In this study, firm value is measured by Price Book Value with the formula as follows:

Price Book Value $=\underline{\text { Market Price Per Common Share Sheet Book }}$

Value Per common share

Book Value Per common share $=\quad$ Common Stock Equity

Number of ordinary shares outstanding

\subsection{Investment Decision ( $\mathrm{X}$ )}

According to Pujiati and Widanar (2009), it is stated that investment decisions are decisions issued by companies related to company activities to release funds at the present time with the hope of generating future fund flows with amounts greater than those released at the time of the initial investment. The company's expectation to always grow and develop will be more clear and planned.

Investment decisions are decisions on assets managed by the company. Investment is defined as investment in a company. Investments can be made in real assets or financial assets. In this study, investment decisions are proxied by PER (Price Earning Ratio). PER is seen by investors as a measure of the company's strength to generate profits in the future. PER will show how management generates profits in investment decisions that are formulated by (Wijaya and Wibawa, 2010): 


\subsection{Corporate Social Responsibility (CSR)}

According to Fahmi (2013) Corporate Social Responsibility is the commitment of the company or the business world to contribute to sustainable economic development by paying attention to corporate social responsibility and emphasizing the balance between attention to economic, social and environmental aspects. Meanwhile Saleh et al (2019) stated that corporate social responsibility is defined as a business operation that is committed not only to increase company profits financially, but for regional socio-economic development in a holistic, institutionalized and sustainable manner.

CSR or corporate social responsibility is seen as an obligation that agreed between the company and the community, where the community gives permission to the company alam to manage its natural and human resources in carrying out its operations. Irfansyah (2020) argues that human resources are a crucial problem in an organization to be considered for the progress of the organization or company as expected. Human Resource Development as an effort to improve the quality of the personality, knowledge, skills and abilities of employees. The quality of employees has multi dimensions and has a broad scope along with changing needs. Companies that implement CSR will still get positive benefits, namely get legitimacy from the community which in turn will have an impact on corporate profits in the future.

The calculation of this variable is carried out by the researcher by measuring the social disclosure of the annual report, which is carried out by observing whether or not an item of information is determined in the annual report with the assumption that every one disclosed must have been carried out. Calculation of CSR is done in the following manner: Score 0: if the information item is not in the report finance. Score 1: if the specified information item is in the annual report.

This measurement method is called the data checklist. In this variable, the calculation is carried out by the researcher using the social information index formula to calculate corporate social disclosure, namely:

\section{CSR index $=\underline{\text { Total CSR Disclosure Score }}$ Maximum Score Amount}

\subsection{Company Growth (X)}

According to Machfoedz in Gustian (2017), Growth company is the company's ability to increase its size. Growth (growth) is how far companies place themselves in the overall economic system or economic system for the same industry.

Company growth can also be an indicator of the company's profitability and success. In this case, the company's growth is representative of the availability of internal funds. If the company is successful and makes a profit, there will be sufficient internal funds for investment needs. In this study, company growth can be measured by changes in total assets with the following formula:

$$
\text { Company growth }=\frac{\text { Total assets }()-\text { Total assets }() \times 100 \%}{\text { Total assets }()}
$$




\subsection{Relationships between Variables}

\section{a. The Effect of Investment Decisions on Firm Value Company}

Managers in making investment decisions must have calculated the return to be received. The expected investment decision is the most profitable investment decision for the company.

In the signal theory, it is stated that the company's urge to provide information is because there is information asymmetry between company managers and outsiders because company managers know more about the company and prospects that will come from outside parties. Company could upgrade company value by reducing information asymmetry by giving signals to outsiders, one of which is in the form of positive and reliable financial information which will reduce uncertainty about future company prospects so as to increase the company's credibility and success.

\section{b. The Influence of Corporate Social Responsibility on Company Value}

Increasing Corporate Social Responsibility to society will create a good image of the company, investors are more interested in companies that have a good image in the community because the better the image of the company, the better consumption loyalty. By disclosing good corporate social responsibility, it is done by the company to make it easier for stakeholders to obtain the information needed both in economic, social, and environmental aspects. The company also hopes that corporate social responsibility can maintain good relationships with stakeholders and can improve company performance. With these things can be a positive reaction for the market to increase the stock price. The increase in stock prices reflects that the value of the company is increasing so that it becomes an attraction for investors to carry out investment activities with the company.

\section{c. The Influence of Company Growth on Firm Value}

Company growth is expected by internal and external parties to a company suatu because it can provide a positive aspect for them. From the perspective of investors, the growth of a company is a sign that the company has a profitable aspect and they expect the rate of return (rate of return) from their investment to give better results. How big is the opportunity for a company to invest which is expected in the future to provide a high return for the company. Good company growth is expected to produce a higher rate of return on the investment made. Investors who get information about the company's growth as indicated by an increase in the total assets of a company will get a good response from the market, so that can increase the stock price or reflect the increased value of the company.

Based on the descriptions that have been previously described, the hypothesis of this study are: $\mathrm{H} \neq 0$ : Investment decision, Corporate Social Responsibility (CSR) and growth has a positive and significant effect on company value in the consumer goods sub-sector manufacturing company listed on the Indonesia Stock Exchangein2017- 2019.

\section{Research Methods}

\subsection{Type of Research}

Is a type of causal research that is useful to explain the effect of the independent variable on the dependent variable. Researchers use a causal design or causal relationship.

\subsection{Populationand Research Sample}

The population in this study were 38 manufacturing companies in the sub-sector of consumer goods listed on the Indonesia Stock Exchange with a research period of 3 years, the 
researcher took 16 companies as samples with some predetermined criteria so that the total observation data was 48 observational data. , but there are 9 data that must be eliminated so that the number of observation data is 39 data, data elimination is carried out because at the time of data processing there is a case data which causes the data to be abnormal then casethecasedata mustbediscardedsothat thedataisnormal. Thesamplecollectiontechnique used in this study was purposive sampling, namely the technique of determining the sample based on a certain criteria.

\subsection{Data Analysis Techniques}

The data analysis technique used is multiple linear regression analysis. The tests performed were: Classical Assumption Test, namely the Normality Test, Multicollinearity Test, Hetero scedasticity Test and Autocorrelation Test. Hypothesis testing with test (partial test)and $\mathrm{F}$ test (simultaneous test), coefficient of determination analysis and multiple linear regression analysis.

\section{Resultas and Discussion}

\subsection{Research Result}

a. Classical Assumption Test

\section{Normality Test}

Normality test aims to test whether in the regression model, confounding variables or residuals have a normal distribution or not. A good regression model is to have normal or near normal data distribution. To find out the normality of the researcher data using the normal plot, the results of the normality test can be seen in the image below:

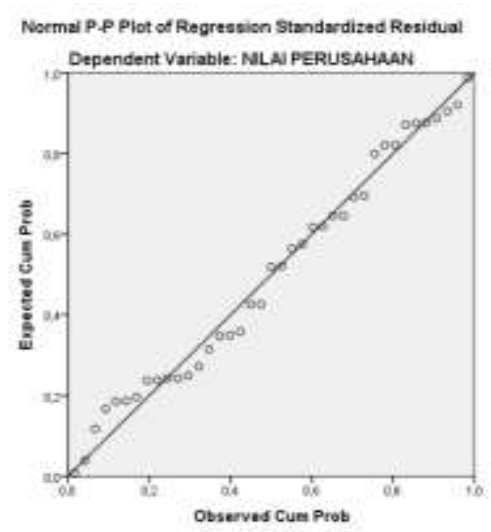

Figure 1. Normal P-P Plot Graph

Source: Results of data processing from SPSS V.21, 2020

Figure 1 above shows that the data spreads around the diagonal line. Therefore, it can be concluded that the data are normally distributed.

The results of the normality test can also be seen in the KS test in table 1 the following: 
Table 1. The One-Sample Kolmogorov-Smirnov Test

\begin{tabular}{|ll|r|}
\hline & & Unstandardized Residual \\
\hline $\mathrm{N}$ & & 39 \\
Normal Parameters ${ }^{\mathrm{a}, \mathrm{b}}$ & Mean &, 0000000 \\
& Std. Deviation & 1,43004731 \\
Most Extreme Differences & Absolute &, 083 \\
& Positive &, 083 \\
& Negative &,- 080 \\
Test Statistic & &, 083 \\
Asymp. Sig. (2-tailed) & &, $200^{\mathrm{c}, \mathrm{d}}$ \\
\hline
\end{tabular}

Source: Data processed by SPSS V 21, 2020

Based on table 1 it is known that the value is significant equal to 0.200 because the value of is significant 0.200 is greater thanthesignificancelevelof0.05. This means that the assumption of normality is fulfilled.

\section{Multicollinearity Test}

Ghozali $(2011 ; 105)$ says "The multicollinearity test aims to test whether the regression model found a correlation between independent variables. In a good regression model there should be no correlation between the independent variables". To test whether has multicollinearity or not, it can be determined by using the tolerance value and as opposed to Variance Inflation Factor (VIF). The cutoff value commonly used to indicate the presence of multicollinearity is a tolerance value $>0.1$ or equal to VIF $<10$. The multicollinearity test results can be seen in the table below:

Table 2. Multicollinearity Test Results

Coefficients $^{\mathrm{a}}$

\begin{tabular}{|l|r|r|}
\hline \multicolumn{1}{|c|}{ Model } & \multicolumn{2}{|c|}{ Collinearity Statistics } \\
\hline & Tolerance & \multicolumn{1}{|c|}{ VIF } \\
\hline 1 (Constant) & & \\
Investation &, 912 & 1,097 \\
Decision &, 922 & 1,084 \\
CSR &, 889 & 1,124 \\
\hline Company & Growth & \\
\hline
\end{tabular}

Source: Data processed by SPSS V.21, 2020

Based on table 2, it can be seen that the VIF value of each variable is below 10 and the tolerance value for each variable is greater than 0.1 so that there is no relationship or correlation between one independent variable and other independent variables. From the table above it can be stated that the research data does not experience multicollinearity so that the existing regression model is appropriate to be used in predicting firm value.

\section{Autocorrelation Test}

The autocorrelation test in this study used the Durbin-Watson test. Here are the results based on the Durbin-Watson test. 
Table 3. Autocorrelation Test with the Durbin-Watson Test

\begin{tabular}{|c|c|}
\hline Model & Durbin-Watson \\
\hline 1 & 2,153 \\
\hline
\end{tabular}

Source: Data Processed by SPSS V.21, 2020

Based on table 3 it can be seen that the DW valueof2.153this value will be compared with a significance table value of $5 \%$, the number of samples $(n)=39$ and the number of independent variables $(\mathrm{k}=3)=3.39$ thentheduvalueis1.657. The $\mathrm{DW}$ valueis2.153greater from the upper limit $(\mathrm{du})$ which is 1.657 andless than $(4-\mathrm{du}) 4-1,657=2,343$ then could concluded that not there is autocorrelation.

\section{Heteroscedasticity Test}

The heteros cedasticity test according to Ghozali (2011: 139) aims to test whether in a regression model there is a residual variance inequality from one observation to another fixed, then it is called heteros cedasticity. The method used to detect the presence or absence of heteros cedasticity in this study is by looking at the Plot graph between the predicted value of the dependent variable, namely ZPRED, and its residual, namely SRESID. Detection of the presence or absence of heteros cedasticity can be done by looking at the presence or absence of a certain pattern on the scatterplot graph between SRESID and ZPRED where the $\mathrm{Y}$-axis is the predicted and the $\mathrm{X}$-axis is the residual (Y-predicted $\mathrm{Y}$-actually) that has been studentized. The results of the heteroscedasticity test can be seen in Figure 2 are:

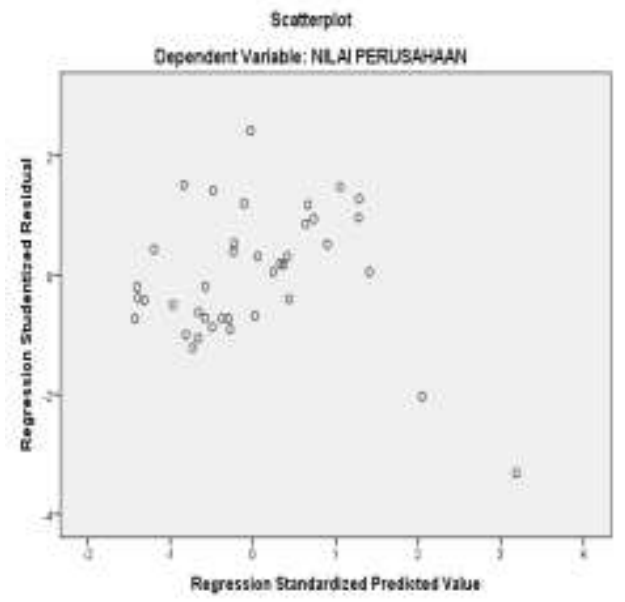

Figure 2. Heteroscedasticity Test Results

Source : Hasil pengolahan data dari SPSS V.21, 2020

From the scatterplot graph above, it can be concluded that the points spread randomly and are spreadbothaboveandbelow the number 0 on the $\mathrm{Y}$ axis. It can be concluded that there is no heteroscedasticity in the regression model, so the regression model is suitable for predicting firm value.

\section{b. Multiple Linear Regression Analysis}

Multiple linear regression analysis is used to determine the influence of variable independent variable (independent), namely investment decisions, Corporate Social 
Responsibility (CSR) and company growth in predicting the dependent variable (dependent), namely the value of the company.

Table 4. Results of Multiple Linear Regression Analysis

\begin{tabular}{|c|c|c|}
\hline \multicolumn{3}{|c|}{ Coefficients $^{\mathrm{a}}$} \\
\hline \multirow{2}{*}{ Model } & \multicolumn{2}{|c|}{ Unstandardized Coefficients } \\
\hline & \begin{tabular}{|c|} 
B \\
\end{tabular} & Std. Error \\
\hline (Constant) & 2,241 & 1,514 \\
\hline Investation & 107 & 026 \\
\hline 1 Decision & & \\
\hline CSR & $-7,016$ & 7,109 \\
\hline Company Growth & 015 & ,018 \\
\hline
\end{tabular}

The results of multiple linear regression analysis obtained after performing the SPSs test are as follows:

Multiple Linear Regression Equation

$$
\mathrm{Y}=2.241+0.107 \mathrm{X}-7.016 \mathrm{X}+0.015 \mathrm{X}+\mathrm{e}
$$

From the regression equation above, it can be described as follows:

1. Kostanta of 2.241 indicates that if the independent variable has a value of 0 then the value of the company value of 2,241 .

2. $\mathrm{X}$ is an investment decision variable which has a regression coefficient value of 0.107 . This means that an increase of $1 \%$ in the investment decision variable, the company value will increase by 0.107 , assuming other variables are fixed.

3. $\mathrm{X}$ is a variable Corporate Social Responsibility (CSR) which has a regression coefficient value of -7.016 . This means that the increase $1 \%$ for the Corporate Social Responsibility (CSR) variable, thecompany value willdecreaseby-7.016, assuming the other variables are constant.

4. $\mathrm{X}$ is a company growth variable which has a regression coefficient value of 0.015 . This means that a $1 \%$ increase in the company's growth variable then the firm value will increase by 0.015 with the assumption that other variables variabel are fixed.

\section{c. Hypothesis Testing}

\section{Coefficientof Determination}

This test is conducted to measure the ability of the independent variables, namely the investment decision, Corporate Social Responsibility (CSR) and growth company in describes the dependent variables, namely firm value.

Table 5. Result of the coefficient of determination

\begin{tabular}{|c|c|c|c|}
\multicolumn{4}{|c}{ Model Summary $^{\mathbf{b}}$} \\
\hline Model & $\mathrm{R}$ & $\begin{array}{c}\mathrm{R} \\
\text { Square }\end{array}$ & $\begin{array}{c}\text { Adjusted } \\
\mathrm{R} \\
\text { Square }\end{array}$ \\
\hline 1 &, $612^{\mathrm{a}}$ &, 374 &, 321 \\
\hline
\end{tabular}

Source: Data Processed by SPSS V.21, 2020 
Based on Table 5, the coefficient of determination located in the Adjusted RSquarecolumn. The coefficient of determination of 0.321 . This value means that all independent variables, namely investment decisions, Corporate Social Responsibility (CSR) and company growth affect the company value variable by $32.1 \%$, and the remaining $67.9 \%$ is influenced by other factors.

\section{Simultaneous Test (Test F)}

The $\mathrm{F}$ test is carried out to determine the joint influence of the independent variable on the dependent variable. The level of significance used is $5 \%$ with degrees of freedom $\mathrm{df}=$ (nk-1), where (n) is the number of observations and (k) is the number of variables and $\mathrm{df}=$ (the number of all variables -1 ).

The test criteria used are:

1. If $F$ count $>F$ table and if the significance $<0.05$ then the influence of all independent variables significantly affects the variable value $(Y)$.

2. If $F$ count $<F$ table and if the significance $<0.05$ then all independent variables have no effect and are not significant to the variable value (Y).

Table 6. Simultaneous Test Results

\begin{tabular}{|ll|r|c|l|}
\hline Model & df & F & Sig. \\
\hline 1 & Regression & 3 & 6,980 &, $001^{\mathrm{b}}$ \\
& Residual & 35 & & \\
& Total & 38 & & \\
\hline
\end{tabular}
Source: Data Processed by SPSS V.21, 2020

By using a 95\% confidence level and a significant level of 0.05 , df $1=$ the number of variables $-1=3+1-1=3$ anddf 2 (nk-1) or $39-3-1=35$, then the $\mathrm{F}$ is 2.87 .

Based on table 7 , the calculated $F$ value $>F$ table $(6,980>2.87)$ with a significance level 0 , of $0.001<0.05$. It means that investment decisions, Corporate Social Responsibility (CSR) and company growth have a significant effect on the value of the company.

\section{T Test (Partial Test)}

The $\mathrm{t}$ test was conducted to test the regression coefficient partially from the independent variables. The level of significance used is $5 \%$, with degrees of freedom $\mathrm{df}=$ (nk-1), where (n) is the number of observations and (k) is the number of variables. The test criteria used are:

1. If $\mathrm{t}$ count $>\mathrm{t}$ table (nk-1), if $\mathrm{p}$ value $<0.05$, it proves that each independent variable has a significant effect on the variable value $(\mathrm{Y})$.

2. If $t$ count $<t$ table (nk-1), p value $>0.05$, so each independent variable has no effect on the variable value $(\mathrm{Y})$. 
Table 7. Partial Test Results

Coefficients $^{\mathbf{a}}$

\begin{tabular}{|ll|c|c|}
\hline \multicolumn{1}{|c|}{ Model } & t & Sig. \\
\hline (Constant) & 1,480 &, 148 \\
& Investation & 4,066 &, 000 \\
(Decision &,- 987 &, 330 \\
& CSR &, 845 &, 404 \\
\hline
\end{tabular}

Source: Data Processed by SPSS V.21, 2020

Tablet value with $\mathrm{df}=\mathrm{n}-\mathrm{k}-1=39-3-1=35$ then the value of $\mathrm{t}$ table is obtained at 1.689. Based on the result testing Partial (test $t$ ) from table 7 can be concluded as follows:

1. The investment decision variable has value $t>$ where $4.066>1.689$ with a significance level of $0.000<0.05$ so it can be stated that the investment decision has a significant positive effect on the value of the company.

2. The variable Corporate Social Responsibility (CSR) has a value of $t<1,689$ with a significance level of $0.330>0.05$ so it can be stated that Corporate Social Responsibility (CSR) has no effect on the value of the company.

3. The company growth variable has a value $\mathrm{t}<\mathrm{t} 0.845<1.689$ with significance level $0.404>0.05$ so it can be stated that the company's growth has no effect on the value of the company.

\subsection{Discussion of Research Results}

a. The effect of investment decisions on firm value

From the partial test results, the investment decision variable has value $t>$ where $4.066>1.689$ with a significance level of $0.000<0.05$ so that it can be stated that investment decisions have a significant positive effect on value of the company.

b. The influence of Corporate Social Responsibility on firm value

From the partial test results, the Corporate Social Responsibility (CSR) variable has a value of $t<$ tdimana $-0,987<1,689$ with a significance level of $0.330>0.05$ so that it can be stated that Corporate Social Responsibility (CSR) has no effect on the value of the company.

c. The influence of company growth on firm value

From the partial test results, the company growth variable has a value of $t<t$ where $0.845<1.689$ with a significance level of $0.404>0.05$ so it can be stated that company growth has no effect on the value of the company. The effect of investment decisions on firm value From the simultaneous results, thevalueof $F$ count $>F$ table $(6,980>2.87)$ with a significance level of $0.001<0.05$. It means that investment decisions, Corporate Social Responsibility (CSR) and company growth have a significant effect on value of the company.

d. The effect of investment decisions on firm value

From the simultaneous results, thevalueof $F$ count $>F$ table $(6,980>2.87)$ with a significance level of $0.001<0.05$. It means that investment decisions, Corporate Social Responsibility (CSR) and company growth have a significant effect on value of the company. 


\section{Conclusion}

Based on the results of hypothesis testing and referring to the formulation and objectives of this research, the following conclusions can be drawn: Partially, it shows that investment decisions have a significant positive effect on firm value, Corporate Social Responsibility (CSR) has no effect on value company and company growth has no effect on the value of the company. However, simultaneously, investment decisions, Corporate Social Responsibility (CSR) and company growth significantly influence the value of the company.

Then the researcher can provide suggestions, including:

1. For further researchers, researchers should expand the sample of companies so that can describe in general all types of companies in Indonesia.

2. For future researchers, it is better year research plus to expand observations that the results obtained are more precise.

3. Future research should measure firm value with another proxy, namely Price Earning Ratio (PER), Market Book Ratio (MBR) and Tobin's Q.

\section{References}

Brigham, Eugene F dan Houston, Joel F. 2011. Dasar-dasar Manajemen Keuangan buku 1 \& 2. (Alih Bahasa : Ali Akbar Yulianto). Jakarta : Salemba Empat.

Fahmi, Ismail,2013. "Manajemen Strategis Teori dan Aplikasi”. Bandung: Alfabeta.

Ghozali, Imam. (2011). Aplikasi Analisis Multivariate Dengan Program IBM SPSS 17, Cetakan Kelima, Semarang: Badan Penerbit Universitas Diponegoro

Harmono,2011. Manajemen keuangan berbasis BalancedScorecaard Pendekatan teori, Kasus, dan Riset Bisnis (Edisi 1). Jakarta : Bumi Aksara.

Irfansyah. (2020). TheDutiesandFunctions Performance ofAceh Human Resources Improvement Institutions inScholarship Study ProgramImplementation inAceh Government. Britain International of Humanties and Social Sciences (BIoHS) Journal, P. 160-165.

Pramusinto, N.D., and Daerobi, A. (2020). Labor Absorption of the Manufacturing Industry Sector in Indonesia. Budapest International Research and Critics Institute-Journal (BIRCI-Journal), P. 549-561.

Saleh, A., et al. (2019). Development of Banking CSR Model for Community Empowerment Slum Area in Medan City. Budapest International Research and Critics Institute-Journal (BIRCI-Journal), P. 39-50.

Wijaya dan Wibawa,2010. "Pengaruh Keputusan Investasi, Keputusan Pendanaan, dan Kebijakan Dividen Terhadap Nilai Perusahaan”. Simposium Nasional Akuntansi 13 Purwokerto. 